\title{
KUALITAS PAPAN PARTIKEL AMPAS SAGU BERDASARKAN KADAR PEREKAT ASAM SITRAT
}

\author{
(The Quality of Particle Board Sago Waste on Adhesive Citric Acid)
}

\author{
Beti Endriani, Dina Setyawati, Nurhaida \\ Fakultas Kehutanan Universitas Tanjungpura Pontianak. Jl. Daya Nasional Pontianak 78124 \\ Email: betiendriani1811@gmail.com
}

\begin{abstract}
This research was to aimed the quality of particle board made from sago waste on citric acid. Particle board made from sago waste from Ambawang Subdistrict, the Regency of Kubu Raya. The research was conducted at the Wood Workshop Laboratory, Wood Processing Laboratory, Faculty of Forestry and PT. Duta Pertiwi Nusantara. Particle size with 8 mesh - 10 mesh and Adhesive citric acid levels were 10\%, 20\%, 30\%, 40\%. Mixing material is done manually. Particle board is made with size $30 \mathrm{~cm} \times 30 \mathrm{~cm} \times 1 \mathrm{~cm}$ with target density of $0,6 \mathrm{gr} / \mathrm{cm}^{2}$. specificpressure of $25 \mathrm{~kg} / \mathrm{cm} 2$ and temperature of $180^{\circ} \mathrm{C}$ for 15 minutes. The quality of particle board comply with a request JIS A 5908-2003 is increasing adhesive citric acid 20\%.
\end{abstract}

Keyword : citric acid, particle board, sago waste.

\section{PENDAHULUAN}

Kebutuhan akan kayu cenderung meningkat seiring dengan meningkatnya permintaan masyarakat untuk memenuhi kebutuhan akan kayu sebagai bahan baku bangunan maupun bahan panel-panel kayu. Saat ini pemanfaatan bahan-bahan bukan kayu dan berlignoselulosa mulai dikembangkan sebagai bahan baku papan partikel, salah satu nya adalah limbah ampas sagu. Limbah ampas sagu mengandung $65,7 \%$ pati dan sisanya berupa serat kasar, protein kasar, lemak, dan abu. Ampas sagu mengandung residu lignin sebesar 21\%, sedangkan kandungan selulosanya sebesar 20\% dan sisanya merupakan zat ekstraktif dan abu (Kiat 2006 dalam Denitasari 2011). Limbah ampas sagu merupakan limbah lignoselulosa yang kaya akan selulosa dan pati, sehingga dapat dimanfaatkan secara optimal sebagai pembuatan papan partikel. Maloney (1997) menyatakan bahwa papan partikel merupakan salah satu jenis produk komposit atau panel kayu yang terbuat dari partikel-partikel kayu atau bahan berlignoselulosa lainnya, yang diikat dengan perekat sintetis atau bahan pengikat lain dan dikempa panas. Pembuatan papan partikel sebagian besar masih menggunakan perekat sintetis yang mengandung formaldehida dan dapat menghasilkan emisi formaldehida.

Penggunaan perekat sintetik dapat diminimalisir dengan cara membuat papan partikel dengan menggunakan sedikit atau bahkan tanpa menggunakan perekat sintetik. Asam sitrat $\left(\mathrm{C}_{6} \mathrm{H}_{8} \mathrm{O}_{7}\right)$ terbukti dapat digunakan sebagai agen pengikat pada produk moulding dari kulit dan kayu akasia Umemura et al. 
(2011) dalam Widyorini et al. (2015). Menurut Syamani et al. (2010) asam sitrat terkandung dalam buah jeruk seperti lemon dan limau. Asam sitrat merupakan bahan yang berpotensi untuk mengurangi penggunaan perekat sintetis yang dapat menimbulkan emisi formaldehida. Menurut Umemura et al. (2011) dalam Widyorini (2012) asam sitrat mempunyai potensi sebagai perekat melalui ikatan kimia dan merupakan salah satu perekat alami yang ramah lingkungan. Asam sitrat juga dapat berikatan dengan baik pada gugus hidroksil dari kayu. Hasil penelitian Aini et al. (2015) dengan menggunakan asam sitrat $0 \%, 15 \%$ dan $30 \%$ dari berat kering dalam pembuatan papan komposit dari serat kenaf, menunjukkan bahwa konsentrasi 30\% menghasilkan nilai yang optimal.

Kualitas papan partikel dapat dinilai dari sifat fisik dan sifat mekanik (JIS A 5908-2003). Adapun sifat fisik papan partikel meliputi pengujian kerapatan, kadar air, daya serap air dan pengembangan tebal. Sedangkan sifat mekanik papan partikel meliputi pengujian keteguhan lentur (MOE), keteguhan patah (MOR), dan kuat pegang sekrup. Saat ini belum diketahui kadar asam sitrat yang optimal dalam pembuatan papan partikel dari ampas sagu, yang memenuhi standar JIS A 5908-2003. Untuk itu diperlukan penelitian mengenai kualitas papan partikel dari ampas sagu berdasarkan kadar asam sitrat yang menghasilkan sifat fisik dan sifat mekanik papan partikel yang berkualitas baik dan memenuhi standar JIS A 5908-2003. Tujuan dari penelitian ini adalah untuk mengetahui kualitas papan partikel yang dibuat dari ampas sagu berdasarkan kadar asam sitrat.

\section{METODE PENELITIAN}

Penelitian dilakukan selama \pm 3 bulan di Laboratorium Wood Workshop serta Laboratorium Pengolahan Kayu Fakultas Kehutanan Universitas Tanjungpura dan Laboratorium PT. Duta Pertiwi Nusantara. Alat yang digunakan adalah mesin ayak, mesin kempa, plat besi, oven, timbangan, gelas ukur, desikator, cetakan ukuran 30 $\mathrm{cm}$ x $30 \mathrm{~cm} \times 1 \mathrm{~cm}$, pistol lem, gergaji potong, mesin bor, mesin UTM, kaliper, hot plate, kapsul stirrer, mikrometer dan thermometer, aluminium foil, semprotan, sedangkan bahan baku yang digunakan yaitu ampas sagu, aquades, dan asam sitrat. Persiapan bahan dimulai dengan menjemur ampas sagu sampai kondisi kering udara, kemudian ampas sagu diayak dengan ukuran lolos 8 mesh tertahan 10 mesh mengacu pada penelitian Maulana et al. (2015). Ampas sagu kemudian dioven dengan suhu $60^{\circ}$ $70^{\circ} \mathrm{C}$ sehingga mencapai KA $7 \%$. Kadar asam sitrat yang digunakan bervariasi yaitu 10\%, 20\%, 30\% dan 40\% (Widyorini et al. 2012) dari berat kering partikel yang dilarutkan terlebih dahulu dalam aquades dan dipanaskan sampai suhu $60^{\circ} \mathrm{C}$. Pencampuran bahan dilakukan secara manual kemudian dicetak.

Papan partikel dicetak dengan ukuran $30 \mathrm{~cm}$ x $30 \mathrm{~cm}$ x $1 \mathrm{~cm}$, dengan target kerapatan $0,6 \mathrm{gr} / \mathrm{cm}^{3}$, pada suhu 
$180^{\circ} \mathrm{C}$ dan tekanan spesifik $25 \mathrm{~kg} / \mathrm{cm}^{2}$ selama 15 menit, kemudian dikondisikan pada suhu ruangan selama \pm 7 hari. Selanjutnya dilakukan pemotongan dan pengujian sampel yang mengacu pada standar JIS A 5908-2003 type 8. Pengujian sifat fisik meliputi kerapatan, kadar air, daya serap air, dan pengembangan tebal. Sedangkan Pengujian sifat mekanik meliputi Modulus of Elasticity (MOE), Modulus of Repture (MOR), dan kuat pegang sekrup. Penelitian menggunakan percobaan rancangan acak lengkap dengan tiga kali ulangan.

\section{HASIL DAN PEMBAHASAN}

Kualitas papan partikel berdasarkan standar JIS A 5908-2003 dapat dinilai dari sifat fisik yang meliputi pengujian kerapatan, kadar air, daya serap air dan pengembangan tebal. Sedangkan sifat mekanik meliputi pengujian keteguhan lentur (MOE), keteguhan patah (MOR), dan kuat pegang sekrup.

\section{Sifat Fisik Papan Partikel}

a. Kerapatan

Nilai rerata kerapatan papan partikel disajikan pada Gambar 1.

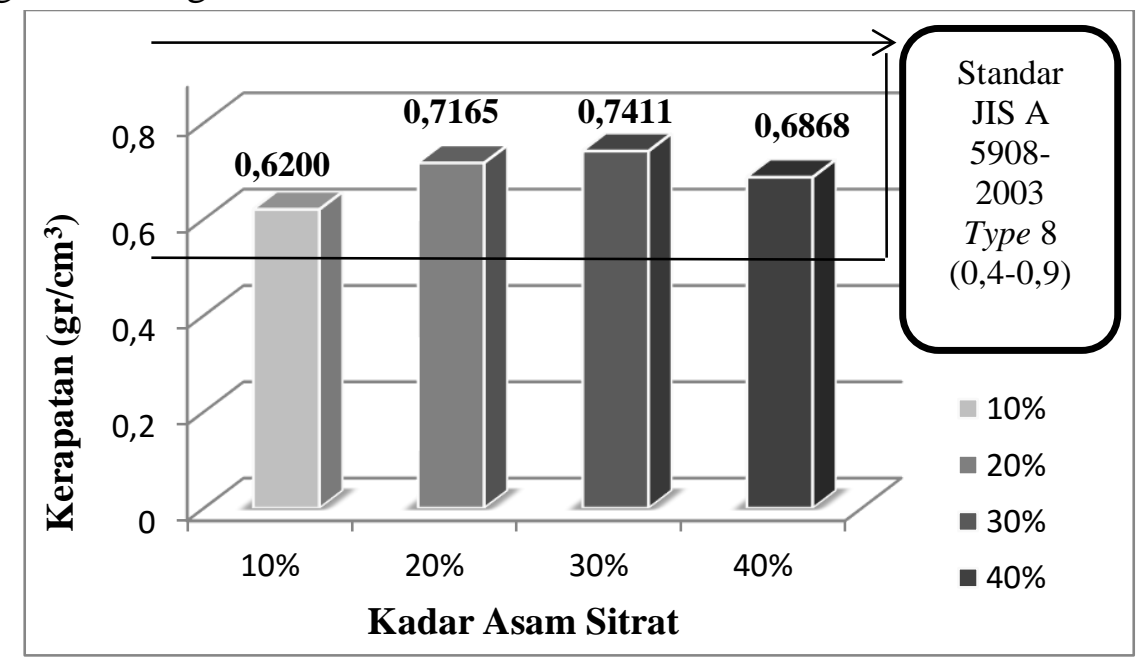

Gambar 1. Nilai Rerata Kerapatan (gr/cm ${ }^{3}$ ) Papan Partikel Ampas Sagu (The average density $\left(\mathrm{gr} / \mathrm{cm}^{3}\right)$ of particle board sago waste)

Perlakuan kadar asam sitrat $10 \%$ 40\% memenuhi standar Japanese Industrial Standard (JIS A 5908-2003) dengan rata - rata nilai kerapatan yaitu $0,6200 \mathrm{gr} / \mathrm{cm}^{3}-0,7411 \mathrm{gr} / \mathrm{cm}^{3}$ dan melebihi standar 0,4. Hal ini terjadi karena kadar perekat asam sitrat yang ditambahkan dalam pembuatan papan partikel, akan menyebabkan bertambahnya berat total dari papan yang dihasilkan pada volume yang sama, sehingga akan menyebabkan meningkatnya kerapatan papan partikel. Aini (2015) menyatakan bahwa nilai kerapatan papan komposit yang terbuat dari serat kenaf dengan penambahan asam sitrat menyebabkan bertambahnya berat dari papan itu sendiri, sehingga nilai kerapatan akan meningkat.

b. Kadar Air

Nilai rerata kadar air papan partikel disajikan pada Gambar 2. 


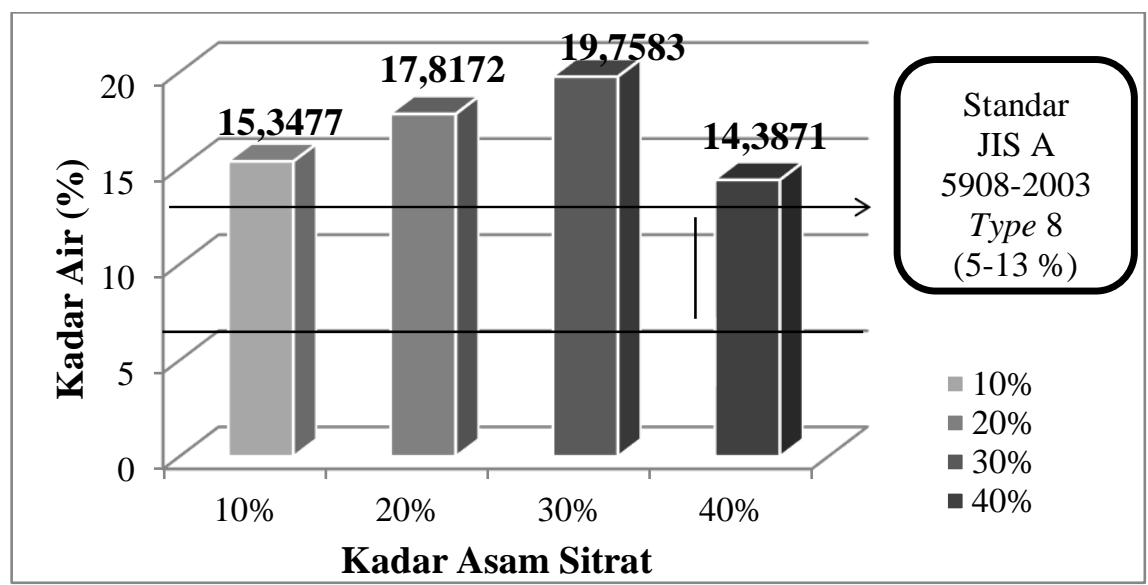

Gambar 2. Nilai Rerata Kadar Air (\%) Papan Partikel Ampas Sagu (The average moisture content (\%) of particle board sago waste)

Perlakuan kadar asam sitrat $10 \%$ $40 \%$ dengan rata - rata nilai kadar air yaitu $14,3871 \%$ - $19,7583 \%$ tidak memenuhi standar Japanese Industrial Standard (JIS A 5908-2003). Nilai kadar air papan partikel yang diisyaratkan standar JIS A 5908-2003 adalah sebesar $5 \%$ - 13\%. Hal ini diduga penggunaan perekat yang berbentuk cair akan menyebabkan meningkatnya jumlah kadar air di dalam papan partikel. Menurut Bowyer et al. (2003) yang menyatakan bahwa apabila pembuatan papan partikel menggunakan perekat cair maka akan menambah kadar air papan partikel sebesar $4 \%$ $6 \%$.

c. Daya Serap Air

Nilai rerata daya serap air papan partikel disajikan pada Gambar 3.

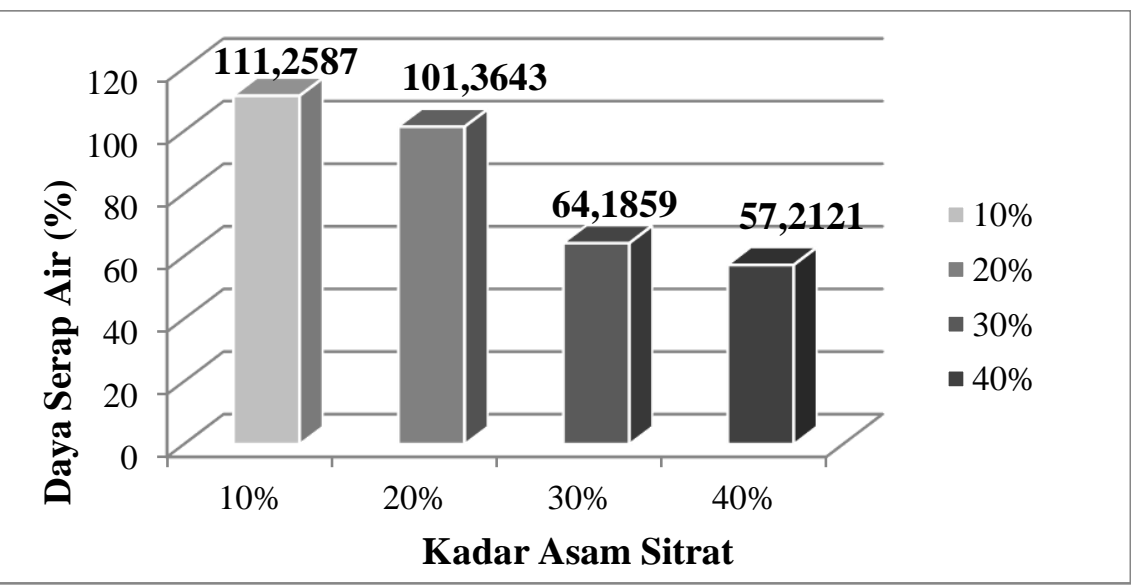

Gambar 3. Nilai Rerata Daya Serap Air (\%) Papan Partikel Ampas Sagu (The average water absorption (\%) of particle board sago waste)

Secara umum hasil penelitian memiliki kecendrungan bahwa semakin tinggi kadar asam sitrat maka nilai daya serap air semakin rendah. Hal ini diduga semakin banyak kadar perekat mengakibatkan semakin kecil kemampuan papan dalam menyerap air. Hal ini dikarenakan ikatan antar partikel 
yang semakin kompak, menyebabkan air ataupun uap air sulit untuk menyerap rongga sehingga daya serap air menjadi kecil (Fathanah 2011). Penurunan nilai daya serap air disebabkan oleh adanya ikatan ester antara gugus karboksil asam sitrat dengan gugus hidroksil dari selulosa (Widyorini et al. 2014).

Penelitian sejalan dengan Widyorini et al. (2012) yang mengatakan bahwa penambahan asam sitrat memberikan pengaruh yang positif terhadap nilai penyerapan air, dimana setelah pemberian asam sitrat nilai penyerapan air menjadi menurun. Semakin banyak jumlah perekat asam sitrat yang ditambahkan, maka akan semakin kecil nilai penyerapan airnya (Aini et al. 2015).

d. Pengembangan Tebal

Nilai rerata pengembangan tebal papan partikel disajikan pada Gambar 4.

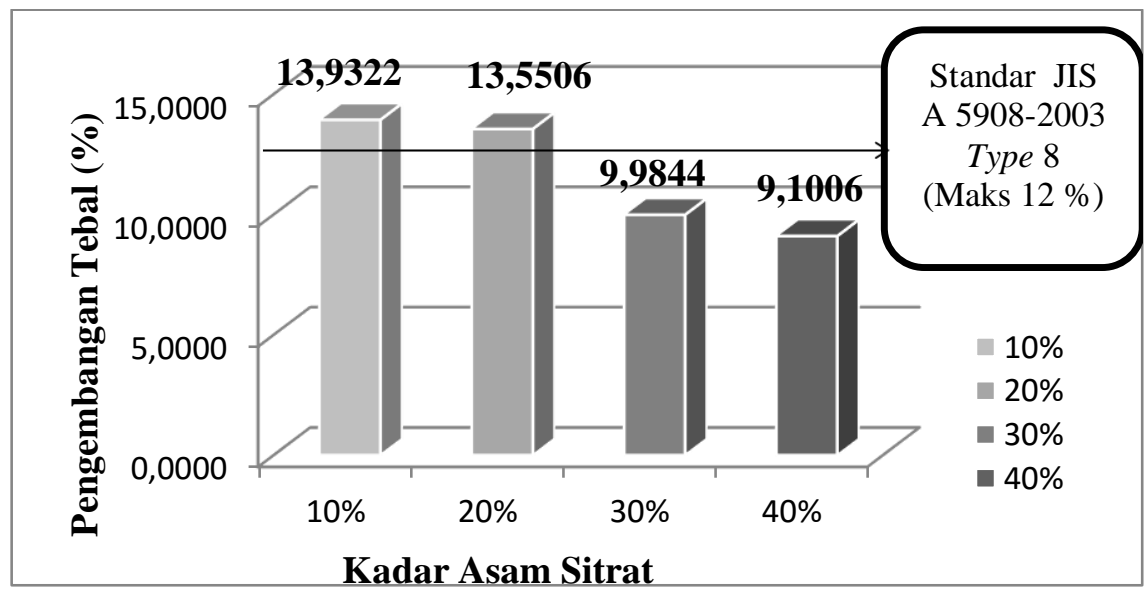

Gambar 4. Nilai Rerata Pengembangan Tebal (\%) Papan Partikel Ampas Sagu (The average thickness swelling (\%) of particle board sago waste)

Pada perlakuan penambahan kadar perekat asam sitrat sebanyak $10 \%-20 \%$ tidak memenuhi standar Japanese Industrial Standard (JIS A 5908 2003). Hal ini diduga karena kadar perekat asam sitrat yang sedikit menyebabkan ikatan antara partikel kurang kompak sehingga papan mudah mengembang. Hasil penelitian ini sejalan dengan penelitian Suroto (2010) yang mengemukakan bahwa jika kadar perekat yang digunakan sedikit maka akan menyebabkan ikatan antara perekat dan partikel kurang kompak dan papan akan mudah mengembang jika dibandingkan dengan kadar perekat yang lebih banyak.

Pada perlakuan penambahan kadar perekat asam sitrat sebanyak $30 \%-40 \%$ memenuhi standar Japanese Industrial Standard (JIS A 5908 - 2003). Hal ini diduga karena semakin banyak perekat yang di tambahkan maka akan menyebabkan ikatan antara perekat dan partikel semakin kompak (Suroto 2010). Hasil penelitian ini juga serupa dengan penelitian Sulastiningsih, Memed dan Sutigno (1988), dalam Arhamsyah dan Rahmi (2010) yang menyatakan bahwa semakin banyak perekat maka ikatan antara partikel akan meningkat sehingga 
papan partikel yang dihasilkan akan lebih stabil dan lebih tahan terhadap air. Umumnya semakin tinggi sifat pengembangan tebal papan partikel maka semakin baik pula daya serap airnya, dan semakin rendah pengembangan tebal papan partikel maka semakin rendah pula sifat daya serap airnya.

\section{Sifat mekanik papan partikel}

a. Keteguhan Lentur (Modulus of Elasticity /MOE)

Hasil pengujian Modulus of Elasticity (MOE) disajikan pada Gambar 5.

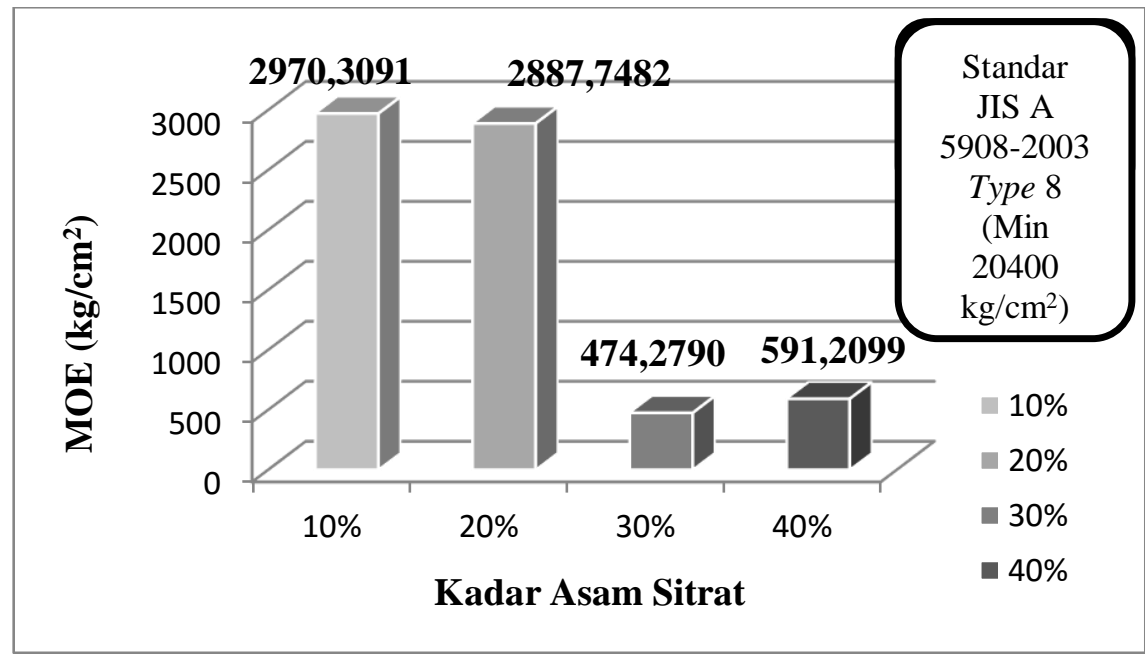

Gambar 5. Nilai Rerata MOE $\left(\mathrm{kg} / \mathrm{cm}^{2}\right)$ Papan Partikel Ampas Sagu (The average MOE $\left(\mathrm{kg} / \mathrm{cm}^{2}\right)$ of particle board sago waste)

Semua perlakuan tidak memenuhi standar Japanese Industrial Standard (JIS A 5908 - 2003). Hal ini diduga karena semakin banyak jumlah asam sitrat maka akan semakin banyak jumlah air yang ditambahkan dalam pembuatan papan partikel, sehingga papan yang dihasilkan lebih lembek dan tidak mampu menahan beban ketika tekanan diberikan. Menurunnya nilai MOE juga diduga karena terjadinya reaksi kimia yang mengakibatkan degradasi dari sebagian selulosa dan hemiselulosa yang menghasilkan gula sederhana dan dekomposisi lainnya dalam bahan baku (Widyorini et al. 2005). Umemura et al. (2011) dalam Widyorini et al. (2005) mengatakan bahwa gugus $\mathrm{OH}$ pada bahan berikatan dengan karboksil asam sitrat membentuk ikatan ester.

b. Keteguhan Patah (Modulus of Rupture/ MOR)

Hasil pengujian Modulus of Rupture / MOR disajikan pada Gambar 6. 


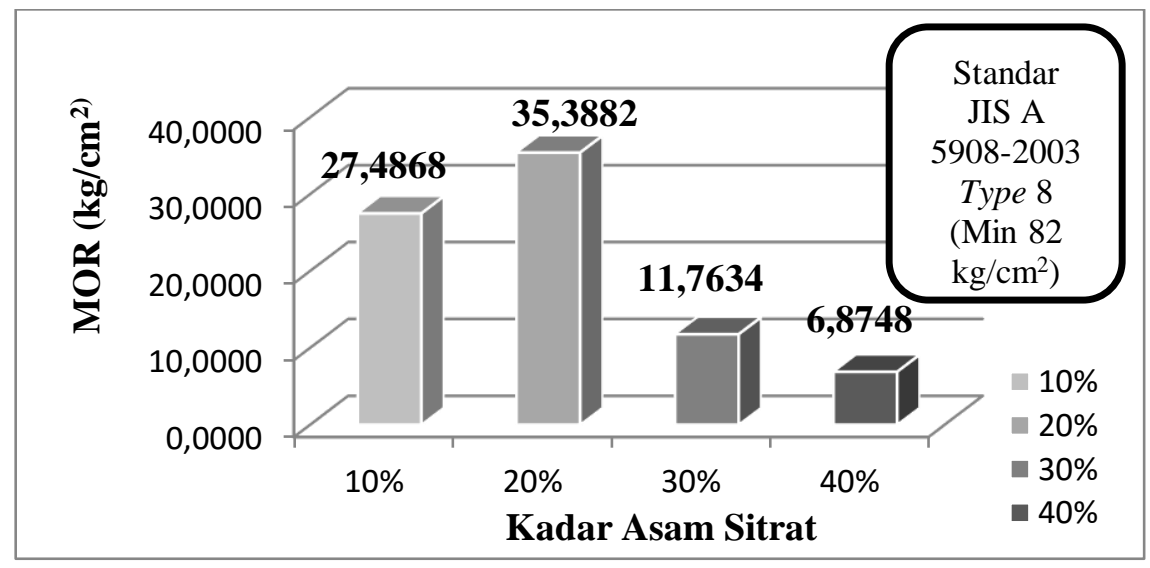

Gambar 6. Nilai Rerata MOR $\left(\mathrm{kg} / \mathrm{cm}^{2}\right)$ Papan Partikel Ampas Sagu (The average MOR $\left(\mathrm{kg} / \mathrm{cm}^{2}\right)$ of particle board sago waste)

Secara umum nilai MOR MOR dipengaruhi oleh kandungan dan menunjukkan penurunan yang signifikan. Hal ini diduga karena pada saat pencampuran partikel dengan perekat tidak merata sehingga mengurangi kekuatan keteguhan patah papan partikel. Penelitian ini sejalan dengan Fauziah et al. (2014) yang menyatakan bahwa tidak mengikat dan saling tidak mengisi antara partikel satu dengan yang lainnya mengakibatkan rendahnya kekuatan patah papan partikel. Maloney (1997) dalam Fauziah et al. (2014) menyatakan bahwa nilai jenis perekat yang digunakan, daya ikat perekat, dan ukuran partikel. Widyorini et al. (2005) mengatakan bahwa beberapa bagian dari asam sinamik pada ikatan ester, terutama pada bahan baku non kayu, mengalami degradasi selama proses pengempaan sehingga mempengaruhi kekuatan self bonding (ikatan yang terbentuk antar partikel tanpa perekat).

c. Kuat Pegang Sekrup

Hasil pengujian kuat pegang sekrup disajikan pada Gambar 7.

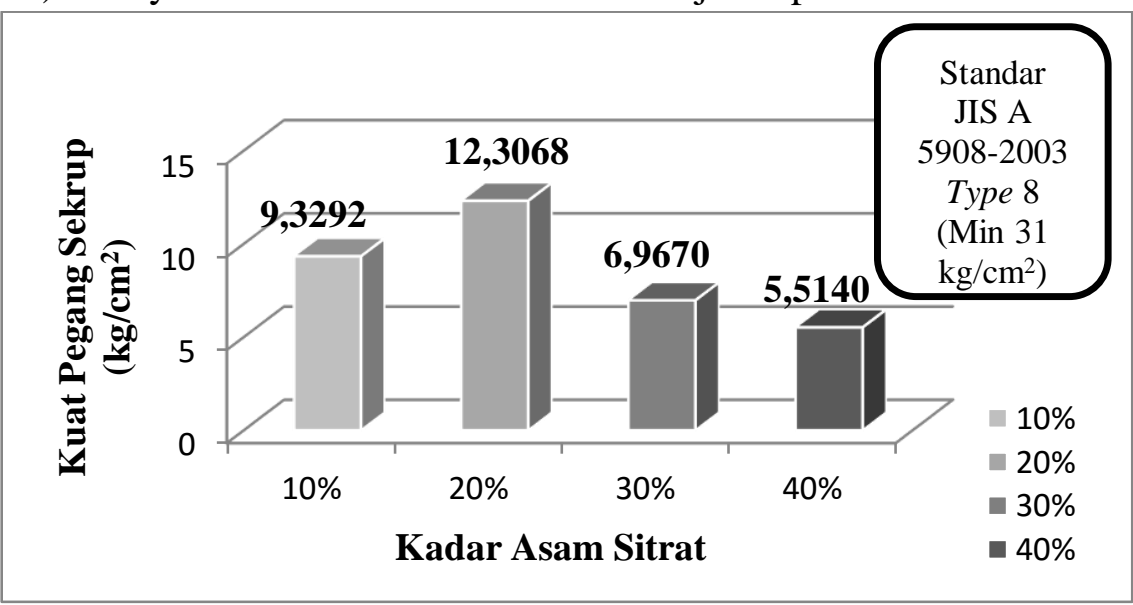

Gambar 7. Nilai Rerata Kuat Pegang Sekrup $\left(\mathrm{kg} / \mathrm{cm}^{2}\right)$ Papan Partikel Ampas Sagu (The average screw holding strength $\left(\mathrm{kg} / \mathrm{cm}^{2}\right)$ of particle board sago waste) 
Secara umum dengan bertambahnya jumlah kadar asam sitrat maka kekuatan kuat pegang sekrup semakin menurun. Menurut Kollmann dalam Firdaus (2010) dalam Suroto (2010) mengungkapkan bahwa penggunaan jumlah perekat dalam papan partikel mempengaruhi sifat-sifat papan partikel yang dihasilkan. Semakin besar penggunaan perekat, semakin besar pula peningkatan kekuatan papan partikel yang dihasilkan, namun demikian pada batasbatas tertentu menyebabkan kekuatan meningkat secara asimtosis, artinya peningkatan kekuatan semakin kecil (Suroto 2010).

\section{KESIMPULAN}

Kualitas papan partikel yang memenuhi standar Japanese Industrial Standard (JIS A 5908 - 2003) adalah kerapatan, daya serap air, dan pengembangan tebal, sedangkan yang lainnya tidak memenuhi standar Japanese Industrial Standard (JIS A 5908 - 2003).

\section{UCAPAN TERIMAKASIH}

Terima kasih kepada Kemenristekdikti yang telah memberikan beasiswa Bidikmisi kepada penulis dan semua pihak yang telah membantu selama proses penelitian hingga proses penulisan.

\section{DAFTAR PUSTAKA}

Aini EN, Widyorini R. 2015. Pengaruh Jumlah Perekat Asam Sitrat Terhadap Sifat Fisika Mekanika Papan Komposit dari Serat Kenaf (Hibiscus Cannabinus L.). Seminar Nasional Masyarakat Peneliti Kayu (MAPEKI) XVIII.
Arhamsyah, Rahmi N. 2010. Pengaruh Kadar Perekat Dan Jenis Bambu Terhadap Sifat Fisis Dan Mekanis Papan Partikel. Jurnal Riset Industri Hasil Hutan 2(1).

Bowyer JL, Shmulsky R, Haygreen JG. 2003. Forest Froduct and Wood Science An Introduction. Fourth Edition. Lowa State Press.

Denitasari NA. 2011. Briket Ampas Sagu sebagai Bahan Bakar Alternatif. Departemen Kimia: Fakultas Matematika dan Ilmu Pengetahuan Alam, Institut Pertanian Bogor.

Fathanah U. (2011). Kualitas Papan Komposit dari Sekam Padi dan Plastik HDPE Daur Ulang menggunakan Maleic Anhydride (Mah) sebagai Compatibilizer. Jurnal Rekayasa Kimia dan Lingkungan 8(2): 53-59.

Fauziah, Wahyuni D, Lapanporo BP. 2014. Analisis Sifat Fisik dan Mekanik Papan Partikel Berbahan Dasar Sekam Padi. Positron 4(2): 60-63.

Japanese Standards Association (JSA). 2003. JIS A 5908-2003 Particleboards. Japan: JSA.

Maloney TM. 1997. Modern Particle Board and Dry Process Fiberboard Manufacturing. Inc San Fransisco: Miller Freeman Inc.

Maulana D, Dirhamsyah, Setyawati D. 2015. Karakteristik Papan Partikel dari Batang Pandan Mengkuang (Pandanus Atrocarpus Griff) berdasarkan Ukuran Partikel dan Konsentrasi Ureaformaldehida. Jurnal Hutan Lestari 3: 247-258. 
Purwanto D. 2016. Sifat Fisis dan Mekanis Papan Partikel dari Limbah Campuran Serutan Rotan dan Sebuk Kayu. Jurnal Riset Industri 10(3): 125-133.

Suroto. 2010. Pengaruh Ukuran dan Konsentrasi Perekat terhadap Sifat Fisik dan Mekanik Papan Partikel Limbah Rotan. Jurnal Riset Industri Hasil Hutan 2(2). Syamani FA, Munawar SS. 2010. Papan Serat Sisal dengan Perekat Ramah Lingkungan Prosiding Seminar Nasional Masyarakat Peneliti Kayu Indonesia (MAPEKI) XIII. Bali .

Syamani FA, Munawar SS. 2010. Papan Serat Sisal dengan Perekat Ramah Lingkungan Prosiding Seminar Nasional Masyarakat Peneliti Kayu Indonesia (MAPEKI) XIII. Bali .

Widyorini R, Prayitno TA, Yudha Ap, Setiawan BA, Wicaksono BH. 2012. Pengaruh Konsentrasi Asam Sitrat dan Suhu
Pengempaan terhadap Kualitas Papan Partikel dari Pelepah Nipah. Universitas Gadjah Mada. Jurnal Ilmu Kehutanan 6(1).

Widyorini R, Yudha AP, Lukmandaru G, Prayitno TA. 2015. Sifat Fisika Mekanika dan Ketahanan Papan Partikel Bambu dengan Perekat Asam Sitrat terhadap Serangan Rayap Kayu Kering. Universitas Gadjah Mada. Jurnal Ilmu Kehutanan 9(1).

Widyorini R, Yudha AP, Isnan R, Awaludin A, Prayitno TA, Ngadianto A, \& Umemura K. 2014. Improving the physicomechanical properties of ecofriendly composite made from bamboo. Advanced Material Research 896: 562-565.

Widyorini R, Higashihara T, Xu J, Watanabe T, \& Kawai S. 2005. Self-bonding characteristics of binderless kenaf core composites. Wood and Science Technology 39: 651-662. 